\title{
Negotiating the German Democratic Republic: Angolan student migration during the Cold War, 1976-90
}

\author{
Marcia C. Schenck
}

\begin{abstract}
Maria
Maria was thirty years old when, in 1985, she boarded a plane in the Angolan capital Luanda to cross the African continent, the Mediterranean Sea and southern Europe to finally land on the grey tarmac of Berlin-Schönefeld in the German Democratic Republic (GDR). The daughter of a housewife and a farmer who later became a nurse, she grew up with four siblings in a mixed suburb of Luanda. Her parents were active in liberation movements, which, together with the discrimination experienced at a largely white school and in their neighbourhood, made the young Maria keenly aware of inequality. After her father had been imprisoned and her cousin killed by a reckless Portuguese driver who went unpunished, fourteen-year-old Maria decided in 1969 'that I needed to do something to liberate our country'. In the early 1970s, she became active in clandestine student underground cells of the People's Movement for the Liberation of Angola (MPLA). An informant of the Portuguese secret police (PIDE) infiltrated her cell and Maria, a ninth grader at a technical school in Luanda, was imprisoned. She was released early in the aftermath of Portugal's Carnation Revolution in April 1974 and moved to Congo-Brazzaville. Part of the People's Armed Forces of Liberation of Angola (FAPLA, the armed wing of the MPLA), she continued her schooling in exile until twelfth grade. An excellent student, she enrolled for a degree in economics at the University of Angola in Luanda. During her second year, she was forced to abandon her studies; she had been promoted to a senior position in the military and had also become a mother. In Maria's words: 'I was left with the bitter taste that I could no longer study. That is why, when this opportunity of studying in the GDR appeared, I applied ... and went to study there.' She recalls her personal transition from Luanda to the GDR as going smoothly:
\end{abstract}

For me, adaptation was good because I had already lived together with different people. In prison, for example, we were all Angolans but we came from different cultures. I was also already part of the military where I met people from different social classes, and was

\footnotetext{
Marcia C. Schenck received her PhD in history from Princeton University in 2017. Currently, she is a lecturer at the Centre for Global History at the Freie University Berlin. Email: Marcia. schenck@fu-berlin.de

This article draws on parts of my $\mathrm{PhD}$ thesis: 'Socialist solidarities and their afterlives: histories and memories of Angolan and Mozambican migrants in the German Democratic Republic, 1975-2015', Princeton University, 2017. The life history I share at the beginning of this article is based on an interview conducted in Luanda on 28 April 2015. The resulting issues of representativeness, bias and selective recall are discussed throughout this article. Maria is a pseudonym employed to maintain the anonymity of the interviewee. For the same reason, I do not refer to interviewees by their given names in this article.
} 
accustomed to situations of want. For me, it was not too strange also because I learned to accept everybody as they are and therefore I did not find it too difficult to integrate. I ate the German food when I could not cook and when I could I prepared the food to which I was used.

For her, studying in the GDR meant 'more than getting to know a country, to receive an education'. In 1988, she returned to Luanda with a bachelor's degree in political science and administration. She considered the economic and legal knowledge she had acquired useful in the context of her subsequent ministerial work. Maria thought about returning to the GDR for a master's degree, but, for family reasons, she decided instead to take up her studies in addition to her work in Angola in 1990, and she concluded her economics degree at Agostinho Neto University. Since her retirement from the military, she has continued working for the MPLA government in various high-profile positions.

This is a story of a strong woman who fought against colonial oppression, adapted to life in socialist Europe, and succeeded as a woman in a male-dominated workspace, balancing family commitments, education and work, all while maintaining her standing as a loyal MPLA cadre. It seems to be emblematic of a small group of outstanding women of her generation who played an active role in building a postcolonial Angola. When we zoom in on her time in the GDR, however, fault lines become apparent and ambiguities emerge. The success of her degree came at a price, as she struggled to cope with the draconian controls exercised by the authorities over students at her institution, while at the same time demonstrating her willingness to accommodate what to her were incomprehensible rules.

Control was especially pronounced at her academy, which prided itself on being an elite political establishment:

I did not like ... the extensive control of the people, where they were, what they were doing, all this reminded me of the colonial times here and I did not feel very much at ease ... I already suffered a trauma from these things and I really thought about returning and even went to talk to the director ... In the end, I did not return because that was against my military discipline.

Maria framed her experience of control and surveillance against the backdrop of colonialism and drew on her military culture to negotiate it. She did not just accept or accommodate what appeared to her as excessive controls; she challenged those rules with the director. Ultimately, her sense of responsibility vis-à-vis her home country and her desire to obtain a degree that she deemed useful for her future political career in Angola triumphed, and she assimilated to a degree that was acceptable to her and to her institution.

The restrictive travel policy at the academy is one further example of what appeared nonsensical to Maria, who saw herself as being faced with greater restrictions to her mobility abroad than at home:

[I]n Angola, I was able to travel wherever I liked. My big shock upon arriving in Germany was that the academy took away my passport and only returned it when ... I travelled to Angola ... One of my daughters had to have an operation in Russia because that was the only country they would let me go to ... I even went to speak to the director to try and understand this rule. Before I went to Germany, I had already travelled to countries such 
as England, Brazil, Portugal and France and I could not understand why ... I was not even able to travel to West Germany. I thought this was deplorable.

We should relativize her impression that she was mobile in Angola during the civil war. This may be an instance of memory downplaying the degree of violence and the resulting internal restrictions on Maria's movements. Maria subjectively felt free because she was able to travel outside Angola. Born, raised and living in Luanda, the rest of Angola would perhaps have seemed further away than Portugal or Brazil.

In the GDR, Maria had to choose between being a mother and wife and being a student. Initially, she arrived with her youngest daughter, a one-year-old, expecting to live with her while studying. However, the academy informed her that living with her child would negatively impact on her concentration and so she was forced to place her daughter with an East German host family until her father was able to take her back to Angola. In addition, students were not allowed personal phones, and it was often difficult to make calls home because the secretaries were too busy to place them. Maria learned how to circumnavigate this frustration by calling her family from the residence of the Angolan ambassador and from the homes of other friends in Berlin. The strict regulations imposed on students in the academy made it impossible for Maria to integrate her different roles. Unlike in Angola, or for East German women in general, being a mother, wife and employee were seen as competing rather than complementary roles for a successful foreign student in the GDR. The model foreign student, as imagined by the East German government, was a person devoted entirely to their studies, devoid of the distractions of family and work responsibilities. Even though the GDR officially welcomed students of both genders, the conceptualization of the model student was implicitly gendered, making no reference to motherhood or parenthood more generally. This reductionist concept was foreign to Maria, for whom it meant restricting access to parts of her selfhood. While Maria had to accommodate many of the school's rules to fit the mould of a model foreign student, she was able to circumnavigate others.

Another experience familiar to Maria from colonial days was the latent and open racism she encountered:

When I was out with a group of colleagues a man shouted after us, 'If Hitler was still in power, blacks wouldn't be allowed to stroll around.' My colleague asked him whether he would like to repeat this in front of the police and he started to run. So, we had these kinds of situations but we didn't give them too much importance. In a general manner, the people were kind.

In general, Angolan students felt that they could rely on the support of state institutions and they often challenged racist expressions such as in the example above. They acted in the knowledge that racism was illegal in the GDR, a country that prided itself on its solidarity with the non-white world (Slobodian 2015). While its illegality might have rendered racism invisible to bureaucrats and white East Germans, it never disappeared from the lived world of African students (Mac Con Uladh 2005a: 208-17; Ireland 1997: 549). African students not only relied on state organs for protection from racism but also challenged the East German state to do more to mitigate the racism with which many Africans were increasingly confronted (Pugach 2019). 
Maria's gender, skin colour and origin shaped her experiences in the GDR and beyond. As a woman, she participated in a programme that made it impossible for her to integrate her multiple roles as mother, wife, military professional and student. As a black person, she was visibly different and encountered verbal racist attacks. As an Angolan and member of the MPLA, she was used to having more personal freedom, including greater international mobility.

Maria's life covers a turbulent time in Angolan history, from the experience of colonial resistance, to independence and the disputed political leadership struggles that followed. It includes the effects of the hot Cold War on Angola's territory, government and people, and the shift away from communism after the fall of the Berlin Wall. Maria's life also spans the civil wars of the 1990s and early 2000s, the decade dedicated to reconstruction, and finally the post-post-war Angola, starting with the second legislative elections in 2012. She does not, however, accord prominence to these events in her life history (Soares de Oliveira 2015: 201ff.). Her perspective is that of an MPLA fighter; her life history is silent on the competing factions within Angolan postcolonial history. Her long career within the military is an important reminder that Angola's recent past has been marked by forty years of various colonial, interventionist and destabilizing civil wars (Birmingham 2015: 67-123). The permanent state of exception led to the build-up of a strong petro-state within the state, but despite astonishing economic annual growth rates of 15 per cent in the first decade of the new millennium, development remains extremely unequal (Soares de Oliveira 2015: 210-3). The returned students I interviewed emerged from this turbulent time as winners, as urban middle to upper classes in mid- to highlevel leadership positions, from the government to the military, the higher education sector and the economy.

Maria's story is both common and exceptional for the Angolan student experience in the GDR from 1976 to 1990 . Her experience echoes that of others as an Angolan student who received technical knowledge pertinent to her profession as well as political training to form a loyal party cadre, all the while balancing the role of foreign student that was expected of her with her multiple roles as mother, wife and FAPLA employee. Her life and the lives of other students were impacted to varying degrees by the ongoing fighting in Angola. While those living in the larger cities, especially in the capital, enjoyed relative security, the war had a more direct impact on students from the south in particular. Her story illustrates themes common to many students, such as ambiguous experiences of inclusion and exclusion, including racism and separation from her children, and challenges to her freedom of movement and her consumer choices.

She is exceptional because, having been born in the mid-1950s, she belongs to a generation of students who grew up under colonialism and actively participated in the struggle for independence. Not all students were as closely affiliated with the MPLA as she was. Moreover, she did not study at a regular university in the GDR but at an academy connected to the Council of Ministers of the SED (Socialist Unity Party of Germany). She is representative of those students who interrupted a professional career with the MPLA government to study in the GDR, whereas students who came straight from high school had often travelled less extensively and had limited experiences to prepare them for their adaptation in the GDR. Finally, Maria's story provides us with a rare account of an Angolan woman's social experience and a subjective framing of her lived reality during the 
decolonization process and socialist period in Angolan history. Maria's memories of the GDR reflect the ambivalence with which she recalls an experience marked by tension between integration and exclusion, accommodation and resistance, and student and family duties.

\section{Student protest and oral life history}

The term 'student protest', the theme of this special issue, conjures up a focus on organized, collective protest movements, rebellions and revolutions. Sara Pugach (2019) shows how organized African student groups in the GDR protested against the politics of both their home countries and the East German state. For members of these groups, protest took on the form of writing letters, disrupting gatherings and holding unsanctioned meetings. In contrast, the student protest under discussion here moves away from large-scale organized protests to include the negotiation and non-confrontational circumvention of rules and the subversion of ideological arguments. The forms this protest took range from discussions with East German bureaucrats to consumption and travel choices. The emphasis on individual students and their response to life in the GDR does not preclude the political but adds another layer of negotiating everyday student life in a foreign country. Maria's story therefore makes us consider the conditions of student life in East Germany. Her example illustrates how the state's narrow perception of what constituted a foreign student was inscribed onto relationships, and highlights the cost of living in a controlling society. We see the ways in which the daily experiences of foreign students clashed with or conformed to state planners' visions, and how they negotiated their lives abroad by choosing their responses from a spectrum ranging from accommodation to resistance.

Life histories such as Maria's are, in Jan Vansina's words, the 'motherlode out of which flow the data for all other genres of history' (1980: 262). They allow us to foreground the agency of temporary student migrants. Studies that focus on the experience of African students in the former East often do so based on archival sources from the receiving countries and describe the student experience as seen through the lens of state documents. These archives often explore problem cases, and so the resulting stories reflect the plight of African students who were isolated, encountered open and hidden racism, and were dominated by controlling states. This study departs from that victimization narrative by foregrounding students as actors who pursued their own goals and worked with the limits of state power by negotiating, challenging or circumnavigating rules that cut into the freedom Angolan students desired. In addition, oral histories collected between twenty and forty years after the conclusion of their studies in East Germany allow us to embed their migration for education into the life course of the former migrants.

Employing Angolan oral history as commentary about the GDR reverses the point of view, thereby 'provincializing' the GDR. ${ }^{1}$ Further, the students' oral histories serve as important correctives to the written archival record by introducing

\footnotetext{
${ }^{1}$ See Hong (2015) for a study that seeks to provincialize the GDR.
} 
new voices, not with a singular claim to truth or authority, but with the recognition that this rich source opens up new ways of seeing the Angolan student experience in the GDR (White et al. 2001: 3-10). The memories shared are the product of cumulative subjective life experiences and selective recall, but they do speak to how the students remember their biography and agency (Abrams 2010: 7; Tumbly 2013: 7). These oral accounts interweave personal, collective and official narratives, the MPLA history of nation building, and experiences of colonialism and international socialism.

This article focuses on oral history interviews with former students and Angolan government personnel read in conjunction with Angolan and East German archival material. I draw on twenty-one life histories of former students I collected in 2015 in Luanda. ${ }^{2}$ The interviewees were selected through snowball sampling: that is, interviewees alerted me to further potential interviewees, whom I adjusted for generation, gender, training and current profession to represent as many diverse experiences as possible. I do not claim that the sample is representative; it is small, based on acquaintance networks and German embassy contacts, self-selective for those who successfully completed a degree, and has a location bias in the capital. Nevertheless, through the collection of oral life histories, we are able to dive into the personal and private aspects of student migrations, and to tell history as seen through the eyes of those who participated in it. ${ }^{3}$ This in turn allows us to grasp their agency in negotiating, challenging or accommodating the many rules with which they were confronted.

\section{The global Cold War as motivator for Angolan-East German educational cooperation}

The migration for education that took Maria to Germany was the product of the confluence of two socialist states' planning in the name of socialist solidarity and

\footnotetext{
${ }^{2}$ It is important to recognize the collected oral histories as products of a unique intersubjective, performative encounter, influenced by the personalities, genders, ages, class and educational backgrounds of the interviewees and the interviewer (Mould 2009: 87; Maynes et al. 2008: 98-125). I conducted the interviews in Portuguese. During the semi-formal interviews, I took notes and recorded those who agreed with a Livescribe pen. The recorded interviews were transcribed in Mozambique. I coded all transcripts in NVivo for comparison and organization (De Blasio et al. 2009: 104-14; Paschen 2009; Oshinsky 1990). All translations of quotations are my own and have been edited for smooth reading.

${ }^{3}$ A quick note on terminology: I employ the term 'student migration', as borrowed from the migration studies field, to refer to Angolans who studied for their full degree in the GDR. I treat this term as synonymous with the international student experiences of those who migrated for a longer period of time. Most Angolan students remained for at least five years in the GDR. Out of the twenty-one students interviewed, eight stayed longer than ten years. Reasons included taking additional time to complete the degree, continuing for a second degree or doctorate, having married and had a family in the GDR, and/or avoiding a return to a war-torn nation. This latter point is true especially for those students who stayed on in the GDR after the fall of the Berlin Wall because Angola entered an extremely brutal period of war from 1992 to 1994 (Birmingham 2015: 112). The term 'study abroad' would wrongly suggest a short time span away from a central educational experience at home, while the term 'student exchange' would be misplaced in the absence of East German students studying in Angola.
} 
mutual aid. ${ }^{4}$ The route between the newly independent People's Republic of Angola (referred to here as Angola) and the GDR that was open to those Angolan students, workers and apprentices who were selected to participate in state-led circular migration programmes is no longer available today and is understandable only against the historical background of the Cold War. The literature placing Angola within the global theatres of hot 'Third World' Cold Wars is rich, but it neglects the cultural aspects of the Cold War. ${ }^{5}$ Following Pieper Mooney and Lanza's edited volume, which decentres and expands the Cold War to include socio-economic and cultural questions discussed through the lens of personal decisions and individual actors on the periphery (2012: 3), this article seeks to broaden our understanding of the Cold War period as Angolan historical actors remember their lived experience by focusing on bilateral educational cooperation.

Far from being a time of immobility and isolation, the socialist era was marked by flows of people and knowledge, as well as flows of goods, technology and capital. Eastern experts, educators, youth brigades and technical and military personnel were sent southwards, while African schoolchildren, students, workers and job, political and military trainees travelled northwards. Cold warriors battled for the hearts and minds of young people with scholarships and teachers, thereby founding transnational networks of knowledge creation and exchange outside epistemological ties to former colonizers. ${ }^{6}$ International student mobility expanded access to higher education in countries with little internal choice, such as Angola (Vela Ngaba 2012: 187). ${ }^{7}$ It is important to bear in mind that the Angolan story related here is part of a much larger narrative of newly independent states from Africa to the Middle East, which were in dire need of an educated workforce to build their nations, and relied on temporary student migration to send young people to Eastern Europe to gain skills (Burton 2016; Katsakioris 2007).

The MPLA ruled Angola as an aspiring and imagined socialist state. Education was key to building a politically homogeneous and socialist postcolonial Angolan nation, both in terms of the population's technical skills and in terms of ideology. Angola required educated workers to staff its state apparatus, economy and schools after the exodus of 90 per cent of the Portuguese colonizers, who had occupied almost all skilled and semi-skilled jobs (Birmingham 2015: 86; Husemann

\footnotetext{
${ }^{4}$ Harisch $(2017$; 2018) and Madureira (2001) provide details on broader trade relations and cooperation initiatives between the GDR and Angola. As yet, very little work has been done on GDR-Angola relations in general.

${ }^{5}$ For studies examining Angola's hot Cold War, see Bender (1987), Brittain (1998), Chabal and Vidal (2007), Ciment (1997), Fonseca and Marcos (2013), Gleijeses (2002; 2013), Pearce (2015), Shubin and Tokarev (2001), Telepneva (2014) and Westad (2007; 1996-97).

${ }^{6}$ For studies that engage with these migrations, see Bryson (1989), Burton (2016), Dorsch (2008a; 2008b), Eckert (2011), Hatzky (2008; 2015), Hessler (2006), Husemann and Neumann (1994), Kanet (1968), Katsakioris (2007; 2010; 2017a; 2017b), Mac Con Uladh (2005a; 2005b), Matusevich (2009), Müller (2014), Müller (1995), Pugach (2015), Slobodian (2008) and Weiser (1993; 2013). Few of these studies engage the West and East comparatively. One area of fruitful further research would trace an African student population across the system divide, as Eric Burton (2016) has exemplified for Tanzanian students in East and West Germany.

${ }^{7}$ For details on more recent Angolan student migrations, especially to the Lusophone world, see Liberato and Lima de Faria (2014), Liberato (2012) and Lima de Faria (2009). For a historical overview of education in Angola, see Da Silva Neto (2010).
} 
and Neumann 1994: 158). Fewer than 100 university graduates were estimated to reside in Angola in 1976 (Soares de Oliveira 2015: 27). A new emancipated education system was to overcome colonialism's legacy of racism, discrimination and paternalism and instil socialist values in the population. At independence, this lofty vision was confronted with a catastrophic reality of around 85 per cent illiteracy and a severe lack of teachers, schools and materials for years to come, despite foreign intervention. School, professional and university education began to be revamped from 1977 onwards. The goal of restructuring the education system was to strengthen national unity by creating a national consciousness in order to raise patriots and soldiers. Hence, national unity, anti-tribalism, antiracism, integration across classes and Portuguese as the national language became maxims of the new system in an attempt to build a single nation (Hatzky 2015: 138-42). All of these tenets are reflected in the interviews with former students. Inadvertently, the dilapidated state of the education system in Angola immediately following independence created a paradox whereby it became necessary for state and nation building to send large numbers of citizens abroad for educational purposes.

The GDR's enabling of circular migration for education by paying scholarships for foreign students to study in East Germany was based on the perceived necessity to foster good relations with African countries and on the commitment to further the peaceful spread of socialist internationalism worldwide. Antiimperialism, anti-colonialism and solidarity with African freedom movements and young independent nations were crucial tenets of the GDR's self-image (van der Heyden et al. 1993; 1994; Weiser 1993; 2013). Educational cooperation was connected to political and/or economic expectations. This circular student migration was designed to ensure that foreign students returned home with a favourable view of the GDR, to serve as cultural ambassadors for East Germany and to build economic bridges with their home country (Müller 1995: 11-13, 18-29).

We can distinguish three generations of Angolan students in the GDR. Solidarity networks and social organizations sponsored the first generation of about twenty students who came between 1962 and 1978. This dates back to the relationship between the SED and MPLA before the formalization of their ties at independence in 1975 (Husemann and Neumann 1994: 162). The second generation, by far the most numerous with about 600 students, consisted of students who temporarily migrated to the GDR alongside apprentices, participants in national education courses and scientists after the signing of bilateral education agreements in 1976 (ibid.: 162-3). ${ }^{8}$ Their scholarships were provided by the GDR

\footnotetext{
${ }^{8}$ Two state agreements signed in 1976 were key for this transnational education exchange: the first related to scientific-technical cooperation (wissenschaftlich-technische Zusammenarbeit) and the other to cultural-scientific cooperation (kulturell-wissenschaftiche Zusammenarbeit) (Husemann and Neumann 1994: 162). The 1976 agreements described the guidelines and direction of the cooperation but the details were set out in work plans and protocols in the Joint Economic Commission between Angola and the GDR (ibid.:161-2; BArch DR 3/4039 Teil 2). In the GDR, many ministries were involved, among them the Ministry for National Education, the Ministry for Higher Education, the State Secretariat for Vocational Training, the Central Council of the Free German Youth and the Foreign Service, while in Angola the Ministry of Education and the National Scholarship Institute (INABE) cooperated with these ministries.
} 
and supplemented by the Angolan state. My interlocutors stem from this generation. ${ }^{9}$ The third generation encompasses those select students who went to Germany after German reunification in 1990 on their own initiative, selffinanced, or sponsored by companies or institutions such as the German Academic Exchange Service (DAAD). ${ }^{10}$

\section{Working hard to succeed: studying in the GDR}

The Angolan student experience in the GDR between 1976 and 1990 involved considerable formal learning. Returned students emphasized their selection based on meritocratic principles and the importance of their disciplined academic success in the GDR. The interviews reveal an awareness of their responsibility to return home as skilled cadres to support the building of a post-independent Angola. At the same time, they remained acutely aware of the chances of upward social mobility their degrees afforded them. It is important to understand the emphasis on technical learning, responsibility, discipline and meritocracy to understand why students chose individual spontaneous forms of resistance to navigate their East German experience rather than organized forms of protest.

The experience of Angolan students was distinctive in the wider temporary Angolan diaspora in the global East. Angolan labour migrants' experiences were circumscribed by the factory, their colleagues and living in worker hostels, ${ }^{11}$ whereas university delineated the students' universe. Here, they attended classes, studied, were part of clubs and student organizations, and were mentored by Free German Youth (FDJ) students, with whom most also shared rooms in the student dormitories (Müller 1995: 73, 84). ${ }^{12}$ Their world mainly centred on

\footnotetext{
${ }^{9}$ To get a sense of the scale of student migration, we need to look at the numbers of the second generation. By 1979-80, forty Angolan students were enrolled (BArch DR 3/4067 Teil 2). In 198081, 119 Angolan students were registered, compared with ninety-three from Mozambique and 1,285 from all African countries. By 1984-85, there were 295 Angolans; this was the level at which Angolan enrolment remained, while the number of African students overall continued to rise, reaching 2,356 students by 1989 (BArch DR 3/4067 Teil 1). These numbers cover all students present in a given year, including PhD candidates, postgraduate students, university students, college students, students in preparatory courses, students registered for part-time degree courses and training courses, and graduates. The reasons for the stagnation of student numbers from Angola remain unclear but probably include an increasing ability to educate within Angola and to self-finance study abroad along with a weakened interest in higher education in socialist countries.

${ }^{10}$ The German embassy still announces DAAD scholarships for Angolan students and professors from master's level upwards, an offer framed historically by highlighting that many of the former Angolan students in the GDR today assume key positions in the Angolan state, economy and sciences. See 'Alemanha oferece oportunidades de estudo e pesquisa para académicos angolanos', Germany Embassy in Luanda, <http://www.luanda.diplo.de/ Vertretung/luanda/pt/06__Kultur/Studieren__in__Deutschland/aktuelle_Informationen.html>, accessed 28 January 2016. See also Calueto (2017).

${ }^{11}$ The experiences of Angolan and Mozambican workers in the GDR are the subject of my thesis (Schenck 2017).

${ }^{12}$ The state-directed relationships between Angolan and East German students were designed to support the foreign students but simultaneously to control their behaviour. While some remember their experiences as a terrible betrayal (interview, Luanda, 21 April 2015), others describe friendship and even hint at love relationships developing between these involuntary student
} 
studying, technical learning and social mobility. The socialist ideological component of their East German education often took a back seat in their memories, recorded twenty-five years after the fall of the Berlin Wall. Instead, students' narratives mirrored the official MPLA discourse with its emphasis on meritocracy rather than class, ethnic group or family connections. The interviewees saw education as a tool for upward mobility and were conscious of their responsibility as members of a small, select group of chosen Angolan technocrats to contribute to the development of their home nation. Yet, we need to take into account the background of the interviewees to relativize the emphasis on meritocracy and upward social mobility. The vast majority of those interviewed have Portuguese names and parents categorized under Portuguese rule as assimilados, a status conferred on those who were admitted to the ranks of the colonial elite based on their Portuguese linguistic and cultural skills, their education, and their economic independence (Newitt 2007: 53). Thus, the interviewees were mostly the children of a missionary-educated Angolan elite who had absorbed the importance of formal education and perfect Portuguese for their and their children's social mobility and the modernization of the country (Chabal and Vidal 2007: 4-6; Soares de Oliveira 2015: 7-10; Summers 2013: 1, 3, 14). While students did not have to be members of the MPLA or J-MPLA (the MPLA's youth wing), some were affiliated closely with the political elite, as siblings, nephews or nieces of important MPLA politicians. All these are indicators that many interviewed former students hailed from an elite background, in the Angolan context. Thus, their emphasis on meritocracy, while correct to the extent that the majority of students were chosen on the basis of their grades, is also fallacious because it disregards the relative privilege that allowed many of them to succeed in school.

The students' motivation for temporarily relocating abroad was to obtain a university degree. The second-generation students I interviewed came to study German, engineering, medicine, law, agriculture, economics, administration and a range of other social and natural sciences at universities and colleges across the country, from Cottbus to Freiberg, Gotha, Weimar and Zwickau, but with the highest concentrations in Berlin and Leipzig. The interviews mirror the statistics collected by the East German Ministry of Higher Education. ${ }^{13}$ By March 1989, 651 Angolan students had completed a degree in the GDR, while 224 were still enrolled at language schools and various educational institutions. Most of these were able to continue their studies in the unified Germany as the DAAD took over East German scholarship commitments (Dane 2010: 71; Müller 1995: 7).

teams (interview, Luanda, 23 April 2015). This is yet another example of how state control could be subverted.

${ }^{13}$ The statistics of the East German Ministry of Higher Education as of 1 March 1990 may serve as an example: during the 1989-90 school year, 320 Angolan students studied in the GDR, of whom sixty-two were enrolled in preparatory language courses, 161 were regular university students, seven were $\mathrm{PhD}$ candidates, and ninety came for specialized courses. Their subjects included economics, electrical engineering, medicine, tropical and subtropical agriculture, law, chemistry and pedagogy. The Humboldt University and the University of Economic Sciences Bruno Leuschner in Berlin, the Karl Marx University in Leipzig, the Wilhelm Pieck University in Rostock, Technical University Dresden, Technical University Merseburg and the Academy for Administration and Law in Potsdam-Babelsberg were among the most frequented institutions (BArch DR 3/4044). 
The Angolan students in the GDR were far from a homogeneous group. ${ }^{14}$ While my sample does not allow definite conclusions, it points to countrywide recruitment. Most students were in their twenties, although some were as young as seventeen and others close to thirty upon arrival in the GDR. ${ }^{15}$ Some left Angola as independent single adults, curious to see the world; others left their children and partners behind and wrote anxious letters home. Some left straight from school or an Angolan university, while others interrupted their working lives to return to school. Some left Angola for the first time, while others were already young cosmopolitans. ${ }^{16}$ Some had already started learning German in Angola with instructors from the GDR who taught at various institutions, most prominently the University of Angola and the Karl Marx Institute in Luanda. ${ }^{17}$ Students who engaged with East German teachers or worked at ministries alongside East German experts could draw on direct references and tips when preparing for their studies abroad and recalled having been integrated immediately in the GDR through these relationships. Regardless of background and prior familiarity with the GDR, all students were conscious of their chance to gain a higher education degree in their area of interest and of the responsibility that came with this chance. They were therefore eager to perform well and to integrate into the East German learning culture.

\footnotetext{
${ }^{14} \mathrm{O}$ the twenty-one former students I interviewed, eight were female and thirteen male. They were born between 1955 and 1971 across northern and central Angola, including the provinces of Bié, Uige, Malanje, Huambo, Bengo, Lunda Sul and Luanda. Twelve originated from Luanda, which coincides with the capital's dominant role in the Angolan postcolonial MPLA government but also reflects the study's focus location. Some interviewees experienced an extremely mobile childhood, as one parent - usually, but not always, the father - worked for the colonial civil service, most commonly as a nurse.

${ }^{15}$ BArch DR3/3995 Teil 1.

${ }^{16} \mathrm{It}$ is not uncommon to find more than one international student in one family. One interviewee told of a cosmopolitan family gathering for his fiftieth birthday, where German, Russian, English and Spanish were spoken with international spouses after five of ten siblings had studied abroad on scholarships in Czechoslovakia, the Soviet Union, Cuba and the GDR (interview, Luanda, 22 April 2015). Many former students who became part of the educational elite experience theirs as an increasingly transnational world (Summers 2013: 9). Their sense of self derives not least from their international educational experiences, allowing them to build informal networks and connections at home and abroad based on these affiliations. In 2000, an attempt to formalize a network of Angolans who had temporarily migrated to the GDR was made when CAARA was formed as 'community of remembrance'. Agostinho André de Carvalho, the only Angolan ambassador to the GDR and an important Angolan author, was the honorary president until 2006. The club had about 100 members and was registered as a non-governmental organization in Angola (Dane 2010: 76-7; interviews, Luanda, 13 and 23 March 2015). Since the club became inactive, Angolan students are now sometimes brought together across personal networks or by invitation through the German embassy.

${ }^{17}$ The Karl Marx Institute in Luanda, through which several of my interviewees passed, was a high school (ensino medio) with specialized training in planning, finances, administration and management. From 1978, East German teachers taught various subjects there including Marxism-Leninism, political economy, business administration, domestic trade, mathematics and administration. Most came from the University of Economic Sciences Bruno Leuschner in Berlin (BArch DR 3/B 1542/2). The aim of this cooperation was to teach the necessary skills to run a planned economy to Angolan teachers ('self-help' for sustainable education in Angola) and students (political-ideological and technical education). Specialized schools, such as the Karl Marx and Makarenko Institutes in Luanda and the Friedrich Engels Institute in Huila, produced many of the government and economic technocrats of the young nation. The Karl Marx Institute's friendship club, Angola-GDR, had about 800 members in 1989 (BArch DR 3/3952).
} 
Having to measure their achievements and assert themselves in relation to German fellow students featured prominently in the interviews because this was an ambivalent experience, simultaneously a source of pride and of profound anxiety: 'We were afraid to fail because we had a very well thought-through, rigorous and highly demanding curriculum. In order to get the desired grades we needed to really be good and we cried many times.' ${ }^{18}$ The quote demonstrates the pressure that some students experienced. However, others derived selfaffirmation from a competitive environment. In the words of one interviewee, 'I was just as smart as the Germans and proved that over and over again!'19 Many students emphasized a narrative that highlighted both initial struggles and final triumphs. The Angolan Student Union (ASU), which served as the representative organ of all Angolan students in the GDR, provided study support groups, boosted student morale, and intervened on behalf of individual students with university administrations, all in an effort to allow as many students as possible to succeed academically. The three ASU presidents I interviewed all took their roles representing Angolan students very seriously but had to admit that, confronted with the East German university apparatus, their room for negotiation was limited:20

As you know the German education system is very rigorous ... it was a very selective and challenging system and we also never succeeded to get around it. Germany was always unrelenting: who did not pass [the exams] for the third time had to return home without finishing the course ... perhaps that is why we have the quality of graduates that we have. ${ }^{21}$

Despite the best efforts of all involved, about 20 per cent of Angolan students were sent back for a mixture of disciplinary issues and underachievement. ${ }^{22}$ The East German system was not fully equipped to meet different students' demands; students suffering from psychological and physical illnesses or students who became pregnant were quick to be labelled as problem cases, without considering their struggle to adapt to a different climate, cuisine and way of living.

Angolan students were not submitted to the same degree of ideological indoctrination as East German students. African students were not members of the FDJ and often voiced their political dissent, as discussed by Pugach in this special issue (2019). Authorities thought it better to teach Marxism-Leninism separately to those foreign students from non-socialist countries or with 'bourgeois' backgrounds to prevent cross-fertilization of unorthodox socialist exegesis (Mac Con Uladh 2005a: 191-2). Yet, socialism was at the forefront of the student experience.

\footnotetext{
${ }^{18}$ Interview, Luanda, 13 April 2015.

${ }^{19}$ Interview, Luanda, 22 April 2015.

${ }^{20}$ The ASU (União dos Estudantes Angolanos in Portuguese or Union der angolanischen Studenten und Praktikanten in der DDR in German) was officially recognized on 30 March 1976. Before the embassy opened it was the students' only contact with the Angolan government (interview, Luanda, 27 March 2015). While not all Angolan students were members of J-MPLA, they were all mandatory members of the ASU (BArch DR 3/3995 Teil 1). Further research into the ASU is necessary to judge to what extent it was able to represent students' interests against East German or Angolan interests, and in what ways it was a mouthpiece of the MPLA and SED.

${ }^{21}$ Interview, Luanda, 27 March 2015.

${ }^{22}$ BArch DR 3/4044.
} 
Student migration took place within the framework of bilateral agreements between two socialist states and was thus a socialist project. It aimed to expose the students to the experience of living within real East German socialism and studying Marxist-Leninist theory, to help with the building of a socialist society at home and ultimately work towards the goal of a global socialist revolution (Müller 1995: 87).

Maria spoke admiringly of the GDR as a model socialist country, in contrast to Angola, where 'we had a socialist option, but in truth we were not socialist, we were still constructing [a socialist state]'. ${ }^{23}$ Most interviewees, especially those who had grown up mostly in postcolonial Angola, however, remember their decision to study abroad as having been primarily based on personal career development plans rather than on revolutionary ideals, and some are silent regarding socialist beliefs. Given the centrality of the socialist ideology in the students' East German curricula and everyday experiences, one might have expected this aspect to feature more prominently in the interviews. Instead, what emerges is an emphasis on quasi-timeless formal learning and the ability to approach technical problems with the self-confidence to find a solution, which reportedly served interviewees in their careers to varying degrees to the present day. One student who studied at the University of Economic Sciences Bruno Leuschner in Berlin stated:

I do not accept that it is true to say that somebody who read economics in Portugal is better prepared than somebody who studied in the GDR. The fundamentals are the same and economics is an evolving subject and we all have to continue to educate ourselves to stay up to date. ${ }^{24}$

This can be read as a conscious effort to retrospectively cleanse their socialist education of its ideological reputation and to portray it as valuable in the changed politico-economic context of post-socialist Angola. Eric Burton encountered this phenomenon among Tanzanian graduates from East and West Germany, where a two-class system emerged, privileging the graduates from Western universities (Burton 2016: 128-9). This judgement is less pronounced in Angola, where many student migrants of the first and second generations received at least one degree in socialist countries such as the GDR, USSR, Bulgaria, Czechoslovakia, Hungary, Poland and Romania, but also in China, India and Algeria, among others. $^{25}$

Foreign students in the GDR had to return home upon completion of their programme. The non-return of students to their home country questioned both Angola's and the GDR's rationale for investing in the education of the students, namely their contribution to the socialist development of the home country and their promotion of links with the GDR. Not all returned immediately, however; some continued their studies in the GDR or elsewhere; others stayed on in unified Germany as asylum seekers; and some emigrated permanently. One

\footnotetext{
${ }^{23}$ Interview, Luanda, 28 April 2015.

${ }^{24}$ Interview, Luanda, 27 March 2015.

${ }^{25}$ Interviews, Luanda, 27 March and 3 April 2015.
} 
former student's response might be seen as indicative of the general feeling among those who returned home in the spirit of nation building:

There was no doubt; I always had to return. There was a lot of temptation there and many fled to other countries, but I was always convinced that I needed to return ... I felt obligated to come and work for my country. I was the Che Guevara type, I thought I had to liberate Angola, and therefore I felt a responsibility and I knew it was my mission to return. ${ }^{26}$

For many students of the second generation, this meant returning to a country in civil war that tended to be framed through the MPLA's discourse on nationalism and patriotism. In retrospect, an early return proved to be an economic windfall for many who remained active in the MPLA: returnees today work in mid- and high-level management positions in government, education and the economy. The Angolan students' emphasis on success in formal education in East Germany thus paid off for many. It is important to keep in mind this eagerness to perform well and accommodate the East German university learning culture in order to return home with the desired degree. Read against this backdrop, it is comprehensible why the vast majority of Angolan students refrained from large-scale group protests that might have jeopardized their goal and instead preferred to negotiate their everyday experiences individually, choosing from a repertoire ranging from accommodation to resistance.

\section{Negotiating life outside the university: students as people and teachers}

As Maria's story demonstrates, we need to take account of aspects beyond the student experience. We should recognize their roles as mothers and fathers, husbands and wives, travellers, consumers and employees if we are to understand their experiences in the GDR (King and Raghuram 2013: 127-8). Friction arose when Angolan students asserted their own image of what their lives in the GDR should look like. While they abstained from collective protest, they individually resisted, negotiated or circumnavigated rules that infringed on their lives. There are several reasons for the preference for individual and spontaneous negotiations over organized forms of protest. Firstly, Angolan students were conscious of the importance of their education as a tool for social mobility and did not want to jeopardize their chance of what was perceived as quality education. Secondly, the collective of Angolan students was represented through the ASU, which received support from the SED and whose leadership was made up of JMPLA members. Thirdly, the pressure to protest collectively never reached the level of collective outrage that marked African student protest in the Soviet Union because overall living conditions - including education, consumption and integration into East German society - satisfied students to a much greater degree (Hessler 2006).

The lives of Angolan students in the GDR oscillated between inclusion and exclusion. While, on the one hand, East Germans sought to accommodate

\footnotetext{
${ }^{26}$ Interview, Luanda, 4 April 2015.
} 
foreign students to ensure that they had a favourable impression of the GDR as a model real socialist state, in other ways students were made to feel acutely aware of their partial exclusion. Student racist encounters under officially anti-racist socialist regimes and their post-socialist successors are a well-explored theme (AllinaPisano and Allina-Pisano 2007; Blakely 1986: 123-43; Hessler 2006; Pugach 2015; 2019; Quist-Adade 2007). Furthermore, while the GDR was supportive of freedom fighters, institutions were not willing to accommodate students such as Maria who reacted against experiences such as restrictions on her freedom of movement that triggered her prison trauma. In addition, institutions were not forthcoming with help for navigating the family responsibilities of students. Individual histories and emotions had to be subjugated to the collective; in the case of Angolan students, the system offered little opportunity to respond to their specific circumstances regarding the ongoing war in their country of origin. The GDR, like the Soviet Union, would also have preferred to see interracial love relationships suppressed, especially those involving African students from capitalist countries, as each bi-national couple inherently jeopardized the goals of the programme that aimed to have graduates return home to advance their countries along a socialist development path (Carew 2008: 201-8; Mac Con Uladh 2005a: 206; Pugach 2015: 141-2). In this context, committed relationships between Angolan and East German citizens can be read as system-defying acts. ${ }^{27}$ Angolan students navigated this foreign educational, social, political and economic landscape and formed their own opinions; the education received inside and outside lecture halls turned some students into critical thinkers. One student credits his sojourn in East Germany with teaching him 'rigour, perfectionism, diligence, and not to be a yes-man'. ${ }^{28}$ Yet the GDR is often depicted as a grim place for foreigners, who, devoid of much agency, were socially excluded from mainstream society. The image of the GDR that emerges from the Angolans' memories, however, is more ambiguous.

In one of the many ironies of history, Angolan foreign students during the Cold War tended to have more freedom of movement than the average East German citizen. Here, Maria is not representative because she attended an academy closely affiliated to the Council of Ministers. Most universities were less willing or able to restrict foreign student mobility. Hence, cross-border mobility emerges as a central aspect in the portrayal of Angolan students' East German lives and in the assertion of their independence from university administrators. In the eyes of East German technocrats, the students' travels to the West were controversial, whether visiting friends and family or going shopping or sightseeing. Intended or not, crossing the Iron Curtain, even just to spend a night out in West Berlin, became a political statement. Hence, the West was not the blank space to many Angolan students that it was supposed to be for their East German contemporaries. The Wall, that insurmountable bulwark for East Germans, was porous for Angolans:

Although we were educated as socialists in Angola, we never ceased to be capitalists. For instance, I went to Portugal, France and Belgium, which meant I got to know the two

\footnotetext{
${ }^{27}$ Interview, Luanda, 8 April 2015.

${ }^{28}$ Interview, Luanda, 23 April 2015.
} 
worlds. This means that we weren't narrow-minded. Even when I lived in the GDR, we'd always go to West Berlin where we bought our clothes, electric devices and other distractions. We Angolans always thought about this as normal because to us this possibility was never denied. ${ }^{29}$

This student highlights another important element of subversion: consumption. Dissatisfied with the quality of available products in the GDR, the majority of Angolan students frequently shopped in West Berlin. One female student, already a teacher at the MPLA party school in Luanda, studied at the Academy for Social Sciences of the SED's Central Committee in Berlin. The Angolan ambassador Agostinho André de Carvalho took the Angolan students at this institution on trips to West Germany, something the academy deplored but could not prohibit. On one of these trips she bought a colour TV to replace the East German black and white set in her room. The school questioned her, because with her new TV she was able to watch 'West-TV', the prohibited news from the other side of the information divide. She stood her ground, arguing that 'as a student of Marxist-Leninism I need to know how to confront and argue against the other side' ${ }^{30}$ This student subversively instrumentalized East German propaganda to suit her own needs. She was successful not least because the authorities were already aware that many foreign students followed Western media (Mac Con Uladh 2005a: 190).

Overall, Angolan students came from a more liberal interpretation of socialism and the GDR's rules-based real socialism came as a shock to some:

We were a country with a socialist orientation. Now, the fact that we were living in a socialist country did not mean that they could forbid us to travel to the West or wear a T-shirt of Michael Jackson ... This was certainly one of the most lasting impressions of my life, when I was in the GDR I felt isolated like them. I wasn't at ease being in a country where citizens couldn't visit their brothers in another country. Often I traversed that wall [the Berlin Wall] and thought it was horrifying and showed clearly that something wasn't right. The material we covered in our Marxism-Leninism classes was convincing in a certain way but that reality was sad. ${ }^{31}$

Compared with East Germans, Angolan students felt cosmopolitan and privileged. Angolan students' ability to travel put them in a powerful position vis-àvis East German citizens, whose ability to inform themselves about the world was limited. Angolan students became teachers and gateways to the world; their professors and classmates sought them out to gain a glimpse of faraway places such as Angola and prohibited places beyond the Iron Curtain. This exchange from the free to the unfree world would not stop at ideas. One former student remembers:

My German classmates would get to know the world through me. I would bring them something from my stopovers in Rome or London. One time I brought seeds from

\footnotetext{
${ }^{29}$ Interviews, Luanda, 6 and 23 April 2015.

${ }^{30}$ Interview, Luanda, 23 April 2015.

${ }^{31}$ Ibid.
} 
Angola for them to plant and see what would grow. They loved it. They travelled through us, we were their source of explorations. ${ }^{32}$

Of course, material presents and souvenirs were highlights not all students were willing or able to deliver. Some students remember bringing alcohol, ballpoint pens or clothing from their trips to West Berlin. Both the giver and receiver, however, had to be inconspicuous in order to avoid repercussions. This knowledge and goods exchange from South to North and West to East subverted East Germany's carefully constructed propaganda and was the very reason why foreign students were at once wanted and feared, welcomed and integrated but also controlled and reminded of the limits and conditions of their inclusion.

Angolan students in the GDR were subjected to control and struggled to live their complex lives being students as well as parents, partners, political beings, employees and foreigners. Where to travel, what to bring for whom, what clothes to wear, where to go shopping and whom to love were all decisions into which East German officials read political motivations. Everyday behaviour determined what side a student was seen to be on in the polarized Cold War world. The straitjacket of the typical foreign student - single, implicitly male, and devoted to both the study of a skill and Marxism-Leninism - did not fit most Angolan students. While students consciously adapted to many East German expectations to be able to graduate successfully, they also succeeded in maintaining their separate Angolan identity and expectations about their everyday lives, to the chagrin of many an East German university official. Finally, Angolan students applied the techniques of negotiation and discussion honed with East German officials when they were back home; in 1989, the then president of the ASU flew back to Luanda to meet with Angolan president Eduardo dos Santos in order to successfully negotiate that Angolan students in the GDR would be allowed to complete their degrees in Germany, against the recommendations of the Angolan ambassador, and despite the collapse of the East German state and the accompanying rise in violent racist expressions. ${ }^{33}$

\section{Conclusion}

Angolan students in the GDR negotiated the tension between accommodation, circumnavigation and resistance when confronted with rules aimed at controlling their lives. Willing to adapt to the East German learning environment in order to succeed academically, many individuals drew the line at rules that circumscribed their individual freedom of movement, consumer choices and family relations. They responded to such restrictive measures with a repertoire ranging from confrontation to negotiation and circumvention. They were willing to accommodate the host culture to a large degree in order to obtain a quality degree, but they were not willing to accept the same restrictions as East German citizens. Angolan students had more leeway in negotiating their situation because the East German state intended to foster economic and political ties with future allies among their home country's educated socialist elite. These young Angolans were part

\footnotetext{
${ }^{32} \mathrm{Ibid}$.

${ }^{33}$ Interviews, Luanda, 6 and 23 April 2015.
} 
of a post-independence generation of Angolan technocrats who largely qualified abroad, taking up opportunities that resulted from Cold War support for the African decolonization process. The Angolan student programme in the GDR can be seen as successful, though not in the way that state planners hoped.

Socialist planners in both nations aimed to form socialist revolutionaries and technocrats who would be able to build a socialist Angola and link it ever more strongly to the GDR and international socialism. This was not to be. The GDR ceased to exist and Angola formally abolished socialism. The former students today are not building economic and cultural bridges to Germany or promoting world socialist revolution. However, they have been able to draw on the techniques of negotiation, circumnavigation and assimilation honed in the GDR as well as the technical and political knowledge acquired in East German institutes of higher education to build careers at home that firmly place them in Angola's urban political, educational and economic elite.

\section{Acknowledgements}

I would like to thank the Angolan men and women who agreed to speak with me about their East German experiences. Many went out of their way to help me with this research, provided transport, and welcomed me into their Luandan homes. I would like to express my sincere gratitude to Laureano Receado Paulo, Francisca Espirito Santo and Faustina Fernandes Inglês de Almeida Alves, Hendrik Dane and Anna Mikeska for facilitating my research. Further, I thank Emmanuel Kreike, Mariana Candidio, Wendy Belcher, Eric Burton and the participants of the 'Student Activism Reconsidered' workshop at the University of Oxford, held on 28 July 2016, for their thoughtful input to this article. I am also grateful to the staff at the German Federal Archive, the directors and staff of the Angolan National Archives, the Ministry of Education, the National Scholarship Institute, and the Ministry of Foreign Affairs in Luanda for supporting this project. I want to thank the History Department at Princeton University and the Princeton Institute for International and Regional Studies (PIIRS) for their financial support. Many thanks also to the International Research Center for Work and Human Lifecycle in Global History at the Humboldt University in Berlin for providing a quiet place to write and an intellectually stimulating environment. Last but not least, thank you Massalo Araujo, Verena Gois, Inês Alves and Martin Hercules for making me feel at home away from home.

\section{References}

Abrams, L. (2010) Oral History Theory. London and New York NY: Routledge. Allina-Pisano, J. and E. Allina-Pisano (2007) "“Friendship of peoples" after the fall: violence and Pan-African community in post-Soviet Moscow' in M. Matusevich (ed.), Africa in Russia, Russia in Africa: three centuries of encounters. Trenton NJ: Africa World Press.

Bender, G. J. (1987) 'The eagle and the bear in Angola', Annals of the American Academy of Political and Social Science 489: 123-32.

Birmingham, D. (2015) A Short History of Modern Angola. Oxford: Oxford University Press.

Blakely, A. (1986) Russia and the Negro: blacks in Russian history and thought. Washington DC: Howard University Press.

Brittain, V. (1998) Death of Dignity: Angola's civil war. London and Chicago IL: Pluto Press. 
Bryson, J. (1989) 'Study in the GDR', Die Unterrichtspraxis/Teaching German 22 (1): 63-6.

Burton, E. (2016) 'African manpower development during the global Cold War: the case of Tanzanian students in the two German states' in A. Exenberger and U. Pallua (eds), Africa Research in Austria: approaches and perspectives. Innsbruck: Innsbruck University Press.

Calueto, F. (2017) 'Alemanha disponibiliza 120 bolsas de estudo para Angola', Novo Jornal, 29 November, <http://novojornal.co.ao/sociedade/interior/alemanha-disponibiliza-120-bolsas-de-estudo-para-angola-46720.html $>$, accessed 26 October 2018.

Carew, J. G. (2008) Blacks, Reds, and Russian Sojourners in Search of the Soviet Promise. New Brunswick NJ: Rutgers University Press.

Chabal, P. and N. Vidal (2007) Angola: the weight of history. London: Hurst.

Ciment, J. (1997) Angola and Mozambique: postcolonial wars in Southern Africa. New York NY: Facts on File Inc.

Da Silva Neto, T. (2010) História da Educação e Cultura de Angola: grupos nativos, colonização e a indepêndencia. Lisbon: Zaina Editores.

Dane, H. (2010) 'Gründung einer Erinnerungsgemeinschaft' in T. Kunze and T. Vogel (eds), Ostalgie International: Erinnerungen an die DDR von Nicaragua bis Vietnam. Berlin: Christoph Links Verlag.

De Blasio, D., C. F. Ganzert, D. H. Mould, S. H. Paschen and H. L. Sacks (2009) Catching Stories: a practical guide to oral history. Athens OH: Swallow Press and Ohio University Press.

Dorsch, H. (2008a) 'Rites of passage overseas? On the sojourn of Mozambican students and scholars in Cuba', Africa Spectrum 43 (2): 225-44.

Dorsch, H. (2008b) 'Studierende und Schüler aus dem südlichen Afrika in Kuba navigieren zwischen rotem und schwarzem Atlantik', EthnoScripts 10 (1): 7-29.

Eckert, A. (2011) 'Afrikanische Intellektuelle und Aktivisten in Europa und die Dekolonisation Afrikas', Geschichte und Gesellschaft 37: 244-74.

Fonseca, A. M. and D. Marcos (2013) 'Cold War constraints: France, West Germany and Portuguese decolonization', Portuguese Studies 29 (2): 209-26.

Gleijeses, P. (2002) Conflicting Missions: Havana, Washington and Africa 1959-76. Chapel Hill NC: University of North Carolina Press.

Gleijeses, P. (2013) Visions of Freedom: Havana, Washington, Pretoria, and the struggle for Southern Africa, 1976-1991. Chapel Hill NC: University of North Carolina Press.

Harisch, I. R. (2017) 'Bartering coffee, cocoa and W50 trucks: the trade relationships of the GDR, Angola and São Tomé in a comparative perspective', Global Histories 3 (2): 43-60.

Harisch, I. R. (2018) 'Handel und Solidarität: Die Beziehungen der DDR mit Angola und São Tomé und Príncipe unter besonderer Berücksichtigung des Austauschs "Ware-gegen-Ware" ca. 1975-1990'. MA thesis, Vienna University.

Hatzky, C. (2008) 'Bildungspolitik und Transnationalismus im postkolonialen Angola: Dimensionen und Herausforderungen der Kooperation mit Kuba', Africa Spectrum 43 (2): 245-68.

Hatzky, C. (2015) Cubans in Angola: South-South cooperation and transfer of knowledge, 1976-1991. Madison WI: University of Wisconsin Press.

Hessler, J. (2006) 'Death of an African student in Moscow: race, politics, and the Cold War', Cahiers du Monde Russe 1-2: 33-63. 
Hong, Y.-S. (2015) Cold War Germany, the Third World, and the Global Humanitarian Regime. Cambridge: Cambridge University Press.

Husemann, B. and A. Neumann (1994) 'DDR-VR Angola: Fakten und Zusammenhänge zur bildungspolitischen Zusammenarbeit von 1975-1989' in U. van der Heyden, H.-G. Schleicher and I. Schleicher (eds), Engagiert für Afrika: Die DDR und Afrika II. Münster: Lit Verlag.

Ireland, P. R. (1997) 'Socialism, unification policy and the rise of racism in Eastern Germany', International Migration Review 31 (3): 541-68.

Kanet, R. E. (1968) 'African youth: the target of Soviet African policy', Russian Review 27: 161-75.

Katsakioris, C. (2007) 'Transferts est-sud: échanges éducatifs et formation de cadres africains en Union soviétique pendant les années soixante', OutreMers 94 (354-5): 83-106.

Katsakioris, C. (2010) 'Soviet lessons for Arab modernization: Soviet educational aid to Arab countries after 1956', Journal of Modern European History 8: 85106.

Katsakioris, C. (2017a) 'Burden or allies? Third World students and internationalist duty through Soviet eyes', Kritika: Explorations in Russian and Eurasian History 18 (3): 539-67.

Katsakioris, C. (2017b) 'Creating a socialist intelligentsia: Soviet educational aid and its impact on Africa (1960-1991)', Cahiers d'Études Africaines 226: 259-88.

King, R. and P. Raghuram (2013) 'International student migration: mapping the field and new research agendas', Population, Space and Place 19: 127-37.

Liberato, E. (2012) 'A formação de quadros Angolanos no exterior: estudantes angolanos em Portugal e no Brasil', Cadernos de Estudos Africanos 23: 109-30.

Liberato, E. and M. Lima de Faria (2014) 'Generational shifts in Angolan students migrations to Portugal: "grant students", "inheritors" and "new students"', Creative Education 5: 1512-22.

Lima de Faria, M. (2009) 'Cooperação no âmbito do ensino superior: ser estudante angolano em universidades portuguesas', Pro-Posições 20 (1): 45-63.

Mac Con Uladh, D. (2005a) “"Studium Bei Freunden?”Ausländische Studierende in der DDR bis 1970' in C. T. Müller and P. G. Poutrus (eds), Ankunft - Alltag Ausreise: Migration und interkulturelle Begegnungen in der DDR-Gesellschaft. Cologne, Weimar and Vienna: Böhlau Verlag.

Mac Con Uladh, D. (2005b) 'Guests of the socialist nation? Foreign students and workers in the GDR, 1949-1990'. PhD thesis, University College London.

Madureira, L. (2001) “"Kalashnikovs, not Coca-Cola, bring self-determination to Angola": the two Germanys, Lusophone Africa, and the rhetoric of colonial difference' in V. Langbehn and M. Salam (eds), German Colonialism: race, the Holocaust, and postwar Germany. New York NY: Columbia University Press.

Matusevich, M. (2009) 'Probing the limits of internationalism: African students confront Soviet ritual', Anthropology of East Europe Review 27 (2): 19-39.

Maynes, M. J., J. L. Pierce and B. Laslett (2008) Telling Stories: the use of personal narratives in the social sciences and history. Ithaca NY and London: Cornell University Press.

Mould, D. H. (2009) 'Interviewing' in D. De Blasio et al. (eds), Catching Stories: a practical guide to oral history. Athens $\mathrm{OH}$ : Ohio University Press. 
Müller, H. M. (1995) Die Bildungshilfe der Deutschen Demokratischen Republik. Frankfurt: Peter Lang.

Müller, T. (2014) Legacies of Socialist Solidarity: the GDR in Mozambique. Lanham MD: Lexington Books.

Newitt, M. (2007) 'Angola in historical context' in P. Chabal and N. Vidal (eds), Angola: the weight of history. London: Hurst.

Oshinsky, D. M. (1990) 'Oral history: playing by the rules', Journal of American History 77 (2): 609-14.

Paschen, S. H. (2009) 'Archiving oral history' in D. De Blasio et al. (eds), Catching Stories: a practical guide to oral history. Athens $\mathrm{OH}$ : Ohio University Press.

Pearce, J. (2015) Political Identity and Conflict in Central Angola, 1975-2002. Cambridge: Cambridge University Press.

Pieper Mooney, J. E. and F. Lanza (2012) De-centering Cold War History: local and global change. New York NY: Routledge.

Pugach, S. (2015) 'African students and the politics of race and gender in the German Democratic Republic, 1957-1990' in Q. Slobodian (ed.), Comrades of Color: the GDR in the Cold War world. New York NY and Oxford: Berghahn Books.

Pugach, S. (2019) 'Agents of dissent: African student organizations in the German Democratic Republic', Africa 89 (S1): S90-S108.

Quist-Adade, C. (2007) 'The African Russians: children of the Cold War' in M. Matusevich (ed.), Africa in Russia, Russia in Africa: three centuries of encounters. Trenton NJ: Africa World Press.

Schenck, M. C. (2017) 'Socialist solidarities and their afterlives: histories and memories of Angolan and Mozambican migrants in the German Democratic Republic, 1975-2015'. PhD thesis, Princeton University.

Shubin, V. and A. Tokarev (2001) 'War in Angola: a Soviet dimension', Review of African Political Economy 28 (90): 607-18.

Slobodian, Q. (2008) 'Dissident guests: Afro-Asian students and transnational activism in the West German protest movement' in W. Pojmann (ed.), Migration and Activism in Europe since 1945. New York NY: Palgrave Macmillan.

Slobodian, Q. (ed.) (2015) Comrades of Color: the GDR in the Cold War world. New York NY and Oxford: Berghahn Books.

Soares de Oliveira, R. (2015) Magnificent and Beggar Land: Angola since the civil war. Oxford: Oxford University Press.

Summers, C. (2013) 'Education and literacy' in J. Parker and R. Reid (eds), The Oxford Handbook of Modern African History. Oxford: Oxford University Press.

Telepneva, N. (2014) 'Our sacred duty: the Soviet Union, the liberation movements in the Portuguese colonies, and the Cold War, 1961-1975'. PhD thesis, London School of Economics and Political Science.

Tumbly, J. (ed.) (2013) Memory and History: understanding memory as source and subject. New York NY: Routledge.

van der Heyden, U., I. Schleicher and H.-G. Schleicher (1993) Die DDR und Afrika: zwischen Klassenkampf und neuem Denken. Münster: Lit Verlag.

van der Heyden, U., I. Schleicher and H.-G. Schleicher (1994) Engagiert für Afrika: die DDR und Afrika II. Münster: Lit Verlag. 
Vansina, J. (1980) 'Memory and oral tradition' in J. Calder Miller (ed.), The African Past Speaks: essays on oral tradition and history. Folkstone: Dawson.

Vela Ngaba, A. (2012) Políticas Educativas em Angola (1975-2005): entre o global e o local: o sistema educativo mundial. Luanda: Sedieca.

Weiser, E. (1993) 'Zur Bildungshilfe der DDR gegenüber Entwicklungsländern auf dem Gebiet der allgemeinen Bildung. Überlegungen für eine Analyse' in U. van der Heyden, I. Schleicher and H.-G. Schleicher (eds), Die DDR und Afrika: zwischen Klassenkampf und neuem Denken. Münster: Lit Verlag.

Weiser, E. (ed.) (2013) DDR-Bildungshilfe in Äthiopien: interaktive Erkenntnisse, Erfahrungen und Eindrücke. Berlin: Lit Verlag.

Westad, O. A. (1996-97) 'Moscow and the Angolan crisis 1974-76: a new pattern of intervention', Cold War International History Project Bulletin 8-9: 21-32.

Westad, O. A. (2007) The Global Cold War: Third World interventions and the making of our times. Cambridge: Cambridge University Press.

White, L., S. F. Miescher and D. W. Cohen (eds) (2001) African Words, African Voices: critical practices in oral history. Bloomington IN: Indiana University Press.

\title{
Archival sources
}

Angolan Department for Education (Ministério de Educação).

Angolan Foreign Office (Ministério das Relações Exteriores).

Angolan National Scholarship Institute (Instituto Nacional de Gestão de Bolsas de Estudo, INABE).

German Bundesarchiv (BARch), Ministry for Tertiary Education (Hoch- und Fachschulbildung) (DR3), all cited documents from 2. Schicht.

German Bundesarchiv (BARch), Ministry for the Education of the People (Volksbildung) (DR2).

\begin{abstract}
This article traces the experiences of Angolan students who attended East German institutions of higher education between Angolan independence and the fall of the Berlin Wall. Based on oral histories collected in Luanda from twenty-one returned Angolan students in 2015, triangulated with archival material from Angola and the GDR, it argues that students negotiated between accommodation and resistance in their everyday life at the university and beyond. Conscious of the importance of academic success and adaptation to the East German learning culture, Angolan students drew a line when regulations infringed on their personal freedom and responded by engaging East German officials in discussion or simply by circumnavigating the rules. The life history of a female student illustrates how she negotiated between responsibility to formal learning and personal needs within a controlling society. When one considers the conditions of Angolan student life in East Germany as a whole, it becomes apparent that the East German notion of the model foreign student did not map onto the complexities of Angolan student lives. This article sheds light on the student migration of a generation of Angolan post-independence technocrats, many of whom studied in the former East during the Cold War. Through the eyes of Angolan educational migrants, we see the limits and possibilities of the lives of foreign students in the GDR.
\end{abstract}




\section{Résumé}

Cet article retrace les expériences de jeunes étudiants angolais dans des établissements d'enseignement supérieur en Allemagne de l'Est entre l'indépendance angolaise et la chute du mur de Berlin. Basé sur des histoires orales recueillies à Luanda auprès de vingt-et-un étudiants angolais revenus au pays en 2015, triangulées avec des documents d'archives d'Angola et de RDA, l'article soutient que les étudiants transigeaient entre accommodement et résistance dans leur quotidien à l'université et au-delà. Conscients de l'importance de réussir académiquement et de s'adapter à la culture d'apprentissage est-allemande, les étudiants angolais estimaient que la ligne était dépassée dès lors que le règlement empiétait sur leur liberté individuelle et réagissaient en engageant des discussions avec les autorités est-allemandes ou simplement en contournant les règles. Le récit de vie d'une étudiante illustre comment elle transigeait entre son devoir vis-à-vis de l'apprentissage formel et ses besoins individuels dans une société dirigiste. Lorsqu'on considère globalement les conditions dans lesquelles les étudiants angolais vivaient en Allemagne de l'Est, il apparaît clairement que la notion est-allemande d'étudiant étranger modèle ne cadrait pas avec les complexités de la vie des étudiants angolais. Cet article apporte un éclairage sur la migration étudiante d'une génération de technocrates angolais postindépendance nombreux à avoir étudié dans des pays de l'Est pendant la guerre froide. À travers le regard des migrants étudiants angolais, cet article nous aide à voir les limites et les possibilités de la vie des étudiants étrangers en RDA. 